\title{
Public Governance in Accountability of Village Enterprise (BUMDes) Management: a Stakeholders Perspective
}

\author{
Denok Kurniasih* (Corresponding author) \\ Shadu S. Wijaya** \\ Paulus Israwan Setyoko* \\ *Departement of Public Administration, Faculty of Social and Political Science, \\ Jenderal Soedirman University, Purwokerto, Indonesia. \\ denok.kurniasih@unsoed.ac.id \\ **Departement of Public Administration, Nahdlatul Ulama \\ University, Purwokerto, Indonesia
}

\begin{abstract}
This paper discusses the imbalance of the role of stakeholders in the accountability of village enterprise management. One of the stakeholders dominates, this has hampered corporate actions based on public governance on the accountability of BUMDes management. Accountability is only carried out as a form of procedural accountability to the village government and district government. Even though there is a horizontal accountability mechanism to the public, it does not work effectively.

One of the reasons for the accountability failure of BUMDes management is the unclear role and responsibility of stakeholders in managing BUMDes. Rural Communities, Representative Institutions (Badan Permusyawaratan Desa), Private Sector, and the ohter Village Institutions do not have proportional roles and responsibilities in the accountability mechanism for BUMDes management. It means the capacity of stakeholders in the accountability process of BUMDes management is relatively low. Even though the capacity of stakeholders is important to strengthen the accountability of BUMDes management, because all stakeholders can monitor and evaluate the management of BUMDes, so that the dominance of the Headman and BUMDes's manager can be controlled. Therefore, in overcoming the vacancy in the role of stakeholders, this research proposes the need to create an accountability mechanism based on public governance, where all stakeholders will interact with each other with the aim of influencing the results of public policy. They interact with each other in the management of public organizations to fulfill various interests of the community. To integrate the role of stakeholders in the accountability of BUMDes management it is advisable to use an information system that can bring together all stakeholders in managing a BUMDes. The information system can be used to strengthen the accountability model based on public governance on the management of BUMDes.
\end{abstract}

Keyword : BUMDes Performance, Public Accountability, Public Governance, Role of Stakeholders. 


\section{INTRODUCTION}

The emergence of Village Enterprises (BUMDes) is a great hope for the community to live more prosperously. Amid the confusion of the village government in utilizing village funds, establishing BUMDes became a matter of much choice. Ideally with the existence of BUMDes there will be two things that should be realized, namely the welfare of the community and the accountability of village fund management. Through BUMDes it is hoped that the potential of the village will be extracted so that the community has the opportunity to be more empowered. Apart from that, through BUMDes, the funds owned by the village can be more clear and focused.

Management of BUMDes has two different sides of the coin, namely one side as an organization that carries a social mission and the other side is carrying out an economic mission because it must bring benefits to the village (income generated). As a social organization, BUMDes was established by the village government and the community to serve the needs of the community, empower the community, and provide opportunities for the community to be involved in managing BUMDes from the planning process to accountability. Whereas as a profit oriented organization, BUMDes need a professional management system because BUMDes must be able to increase Village Revenue (PADes) and also profit sharing for the community fairly.

BUMDes fund comes from village funds belonging to the village community. BUMDes managers must account for the funds used to manage BUMDes through a clear public accountability mechanism. However, in reality the accountability of BUMDes management still does not have a mechanism that involves the community as its assessors. The dominance of the village head is still too strong. Therefore the village government and the managers of BUMDes must ensure that people involved in managing BUMDes must be given clear and firm roles and responsibilities.

Local governments must assist villages in realizing BUMDes that are capable of encouraging the economy and empowering rural communities. Therefore the local government must ensure that the formation of BUMDes is 
not merely used to channel village funds so that the absorption of the village budget becomes optimal. Local governments must ensure that the establishment of BUMDes by utilizing village funds must be able to be accounted for vertically and horizontally.

Thus, this paper provides an explanation that to further improve the quality of BUMDes management, it is necessary to process public governance in the accountability of BUMDes management. The process of public governance requires clarity on the roles and responsibilities of all institutions involved.

\section{PROBLEM STATEMENT}

looking at the phenomenon of accountability deficits and the magnitude of the potential for the establishment of BUMDes, it is necessary to develop an appropriate public accountability model. The accountability mechanism that has been carried out so far is still limited to vertical accountability, even in the case in the village there has been a failure in implementing vertical and horizontal accountability (Setyoko, 2011). This paper can explain a model that will help rural communities in carrying out public accountability in managing BUMDes based on public governance. The idea of public governance in the accountability of BUMDes management is very urgently stated given the lack of optimal role of stakeholders in overseeing the implementation of BUMDes. The formation of BUMDes is the mandate of Law Number 6 of 2014. The results of this study can be a solution to national problems related to the management of BUMDes. The Problem Statement in this paper is "What is the process of public governance in the accountability of the management of BUMDes?".

\section{STATE OF THE ART}

In the management of government business, the Agency Theory describes the existence of a conflict of interest that is likely to occur between agents (managers) and principal (owner) (Eisenhardt, 1989). Conflicts that are likely to occur in the management of government-owned businesses, among others, relate to the sharing of benefits between shareholders, decisions on who 
services are provided, conflicts about supervision and other authorities (Ghosh

\& Whalley, 2008; Hoskisson, Hitt, Johnson, \& Grossman, 2002; Jensen, 2001). The view of agency theory is a consequence of the birth of a modern management system that requires a clear separation between the owner of the capital (owner) and the management.

The efforts of the central government to encourage the village government to establish BUMDes are an illustration that the village government is required to make corporate efforts by clearly separating the role of the capital owner with the BUMDes management. This is explicitly explained in Law No. 6 of 2014, which explains that the managers of BUMDes must come from outside the village government. The headman is only the shareholder. An accountability process is needed to bridge the two parties in order to trust each other.

Accountability is an important requirement in public management that is developed in a democratic country (Brodkin, 2008). Accountability point towards mechanism given for public functionary to be able to explain and ensure that they have been acting correctly, ethically, and responsible for its performance (Bovens, 2007: 450; Dubnick 2005: 1; Mulgan, 2003; Romzek \& Ingraham, 2000: 240 - 241). Therefore, accountability also related to the effort to build a legitimate government.

The management of BUMDes must prioritize aspects of public accountability, because it involves the use of public funds. However, despite the increasing demands for public accountability, various studies show that many government organizations are unable to realize this public accountability. Boven's study (2007: 447), Dixon, Ritchi \& Siwale (2006: 415), Lodhia \& Burritt (2004: 355) toward public sector financial accountability practice conclude that although accountability mechanism has been established

correctly, that mechanism often broke by the organizer. In the Bovens' view (2007: 447 - 448) this phenomenon called as an accountability deficit, that is a condition of dysfunctional from some accountability mechanism who has been designated and then impacted on the low of government legitimation in public. 
According to Mulgan (2003: 74), accountability deficit in this decentralization era is more cause apprehension when there are many public organizations in the local level given autonomy to manage a fund.

To measure public accountability level on Village Enterprise management, this research using criteria used by Dixon, Ritchie \& Siwale (2006: 408 - 410), Bovens (2007: 459 - 461), Schillemans (2008: 179 - 180), that is vertical accountability and horizontal accountability. Vertical accountability refers to the effort of Village Enterprise management responsibility to authority giver side over it who gives a command, those are village government and local government. Horizontal accountability is a Village Enterprise management responsibility to society village. Public accountability in a whole of Village Enterprise accountability will be established if both of dimensions fulfilled.

The financial resources of Village Enterprise (BUMDes) use village funds which are funds from the central government. This means that the capital used by BUMDes comes from public funds. Therefore, the accountability process must be carried out by involving the public as shareholders. Accountability must be carried out both to the regional government, the central government and the rural community. Meanwhile, the result of Kurniasih, Setyoko \& Imron (2015) research explains that accountability mechanism of programs implementation that has been done during this time still limited to vertical responsibility. It means that the role of stakeholders in the accountability mechanism has not become an important part yet. The result of Setyoko's research (2011) explains that village society tends to careless with public accountability as long as their needs fulfilled. In the handling of the emptiness of the stakeholders role, it needs accountability mechanism based on governance concept.

Public governance is a way when stakeholders interacting each other with the purpose to influence the result of public policy (Bovaird \& Loffer, 2009). Those stakeholders are the citizen, society organization, mass media, the public institution, politician, non-profit organization and so on. They are 
interacted each other in public organization management to fulfill the importance of the society. Explained more advanced, the shift of government to governance meant to democratize state administration (Setyoko, 2011).

On the government era, the government has an important role in manage the society. Meanwhile in governance paradigm, there are much of groups involved directly in the formulation and implementation of public policy (Nelissen, 2002; Chhotray \& Stoker, 2009). The concept of governance calculates all factors and policy areas beyond "main executive" that involved in the process of making policy (Richard \& Smith, 2002). Governance in this case, is a wide concept that represents a whole connection quality between the citizen (private and public society) and the government that contains values of responsiveness, efficiency, honesty, and justice (Ferranti, et.al, 2009).

\section{DISCUSSION}

\section{Problem Public Accountability}

Based on observation result accountability mechanism of Village Enterprises (BUMDes), it is seen that the central position of the headman is inevitable. The headman receives a report from the BUMDes manager and then gives feedback to the BUMDes Manager and Board of Trustees. In addition, the horizontal feedback from the village head is still considered in the village consultation forum. That is, the dominance of village government elements, especially the headman becomes a separate issue in the accountability mechanism of BUMDes. The facts in this study are in line with Kloot and Martin (2001: 61 - 63) who argued that people in rural areas are often less concerned about the accountability issues of his government. The rural community with its paternalistic culture tends to trust every action taken by the village elite, so any decisions made by village officials are considered correct. Meanwhile, the results of this research also strengthen the opinion of Setyoko (2011) which explains that the village community tends to be indifferent to public accountability as long as their needs are met. These nrimo village customs are then used by the village government not to attempt to ensure horizontal accountability for every activity that has been done. 
Bovens (2007: 447), Dixon, Ritchi \& Siwale (2006: 415), Lodhia \& Burritt (2004: 355) argue that although accountability mechanisms have been well established, but the mechanism is often not followed by the program implementor. This fact shows that in the process of reporting BUMDes especially in Banyumas Regency is still considered accountability deficit (Bovens, 2007: 447 - 448) because there are still non-functioning of some established accountability mechanisms. Therefore, accountability mechanisms in the management of BUMDes should be directed towards optimizing the role of many stakeholders through a governance approach that allows many groups and interests directly involved in the formulation and implementation of public policy (Nelissen, 2002; Chhotray \& Stoker, 2009). Through this approach emphasizes the importance of the involvement of many stakeholders who are meant to represent the public, to argue as legitimating the deliberative process, each member must position the forum outside of partisan interests (O'doherty, 2012). People with characteristic gemeinschaft basically have the potential togetherness in his life. Therefore, in meeting the democratic potential of rural communities, local governments need to encourage greater democratic connectivity and political connectivity between participatory forums and wider public spaces (Ercan and Hendriks, 2013).

\section{Public Governance and The Role of Stakeholders}

Based on previous research, obtained information that the big potency of Village Enterprise establishment is not balanced with a satisfy public accountability. The previous research finds that Village Enterprise accountability vertically and horizontally still centered on village governance. It shows that central role and village governance domination especially Headman in Village Enterprise management process. It shows the accountability deficit (Bovens, 2007: 447 - 448), because still encountered some of not working fixed accountability mechanisms. Therefore, accountability mechanism in Village Enterprise management needs to be directed to optimizing from many sides role or stakeholders by governance approach that allows many groups involved directly in the formulation and 
public policy implementation (Nelissen, 2002; Chhotray \& Stoker, 2009). This approach also stresses the importance of the involvement from many stakeholders that is meant to represent public, to argue as the legitimation of discussion process, and every member has to positioning the forum beyond the importance of participant (O'doherty, 2012). Village society with a gemeinschaft characteristic basically has togetherness potency in their life. In order to fulfilled democratic potency in village society, local governance needs to encourage the democratic creativity and bigger politic connectivity between the participative forum and wider public space (Ercan dan Hendriks, 2013). Accountability mechanism in Village Enterprise management needs to be directed to optimize the stakeholders role by the governance approach. Through this approach, public accountability expected more directing on the involvement of the stakeholders in the management of village society public assets. The result of the previous research shows that the organizer has not opened the Village Enterprise management information yet to village society because of unavailable specific information system and utilization optimum media. The transparency of the Village Enterprise management report to village society is implemented by informal approaches such as "gather society" forum.

The fact of the research is in accordance with Mabillard dan Zumofen's opinion (2016: 1-20) that accountability and transparency more important in the implementation of contemporary government. On their view, transparency needs to be encouraged as an approach in public organization implementation. Transparency is looked important because it has an advantage in balancing politic act complexity, administrative and social. (Ingrams, 2017).

The result of the observation is in accordance with Hosseini, et.al's finding (2012) in the development of village business group. He shows that village small business has an important role to create job vacancy and produce a valuable product in the certain sectors like agriculture. Nevertheless, the main challenge for this village company is the lack of sustainable. On Hosseini, et.al's view (2012) innovation and cooperation inter the stakeholders is a key to 
the sustainable of village small business. If the existence of innovation and cooperation are not concerned, there is no sustainable for village small business. Smith and McColl (2016) propose that the difference between business activity in the village and the city is not a new case. The distinct comparator is the size such as social architecture, the resources availability and accessibility. They opine that the main difference between social management of village company and the city influenced by migration level in the village and the city, the leadership, society needs. Therefore, it needs a relevant context policy. Although the development of village business group looked great, Chen, Woods dan Singh (2014) propose that Village Enterprise that is managed based on local government planning combination and market power. Therefore, the hybrid character from organization structure and the ownership makes a change in village business group still a lot done in a top-down way.

In handling of this emptiness, it is needed accountability mechanism based on governance concept. Public governance is a way when the stakeholders interacted each other with the purpose to influence the result of public policy (Bovaird \& Loffer, 2009). The stakeholders are the citizen, society organization, mass media, the public institution, politician, non-profit organization, and so on. They are interacted each other in public organization management to fulfill the society needs. Explained more advanced, the shift of government to governance meant to democratize state administration (Setyoko, 2011). On the government era, the government has an important role in manage the society. Meanwhile in governance paradigm, there are much of groups involved directly in the formulation and implementation of public policy (Nelissen, 2002; Chhotray \& Stoker, 2009). The concept of governance calculates all factors and policy areas beyond "main executive" that involved in the process of making policy (Richard \& Smith, 2002). Governance in this case, is a wide concept that represents a whole connection quality between the citizen (private and public society) and the government that contains values of responsiveness, efficiency, honesty, and justice (Ferranti, et.al, 2009). Through public management which is oriented towards governance approaches, this 
research can explain the importance of values that are not only related to efficiency, effectiveness and economics, but also responsiveness in the implementation of BUMDes. Therefore, by using a governance approach, the accountability mechanism in managing BUMDes can be done vertically and horizontally through optimizing the role of stakeholders.

\section{CONCLUSION}

It can be concluded that the large potential of BUMDes establishment, not balanced with adequate public accountability. Responsibility mechanisms conducted either vertically, or horizontally still have not run optimally. The study also found that BUMDes accountability both vertically and horizontally is still central to the headman (village government). It shows the central role and dominance of the headman in the BUMDes management process.

Therefore, in the future accountability mechanisms in the management of BUMDes should be directed towards optimizing the role of stakeholders through a governance approach. Based on the fact in the research, it can be concluded that governance capacity that the village had still belongs to weak. It can be seen from the imbalance role happened. On the one side, the role of the headman and village government is very strong and dominant. In the other side, the role of the other stakeholders still belongs to weak. It makes an accountability deficit in Village Enterprise management. This research can be concluded that in handling the emptiness of the stakeholders role, it is needed an accountability mechanism based on governance, where the stakeholders interacted each other with the purpose to influence the result of public policy. They are interacted each other in public organization management to fulfill the society needs. 


\section{REFERENCES}

Akinseye U, Olowu \& Taye-Faniran Adebowale F. 2016. "The Fear of Business Failure and Government's Role in Supporting Entrepreneurs in Nigeria”. Ife PsychologIA, 24(2): 318-330.

Bovaird, T \& Loffer, E (Eds), 2009. Public Management and Governance, second edition, Routledge.

Bovens, M., 2007. "Analysing and Assessing Accountability: A Conceptual Framework",

European Law Journal, Vol. 13, No. 4: 447-468.

Brodkin, Evelyn.Z, 2008. Accountability in Street-Level Organizations, Journal of Public Administrations, No. 31: 317-336.

Brusca, I. \& Montesinos, V. 2006. "Are Citizens Significant Users of Government Financial Information?”, Public Money \& Management, Vol. 26 No. 4: 205 - 209

Bruton, Gery. D, Peng, Mike. W, Ahlstrom, David, Stand, Ciprian \& Xu, Kehan, 2015. Stated-Owned Enterprises Around The World As Hybrid Organizations, The Academy of Management Perspectives, 29(1): 92114.

Chen, Weifeng, Adrian Woods and Satwinder Singh. 2014. "Organisational change and development of reformed Chinese township and village enterprises". Journal of Organizational Change Management, 26(2): 35336.

Chhotray, V \& Stoker, G, 2009. Governance Theory and Practice: A CrossDisciplinary Approach,

New York: Palgrave Macmillan.

Clark, Jill K. \& Matthew Record. 2017. "Local Capitalism and Civic Engagement: The Potential of Locally Facing Firms". Public Administration Review, 00(00): 1-13.

Dahan, Nicholas. M., Doh, Jonathan. P., Raelin, Jonathan. D, 2015. "Pivoting the Role of Government in The Business and Society Interface: A Stakeholder Perspective", Journal Business Ethics, 131: 665-680.

Daly, Peter. 2017. "Business apprenticeship: a viable business model in management education",

Journal of Management Development. 36(6): 1-7.

Demircioglu, Mehmet A. 2017."Reinventing the Wheel? Public Sector Innovation in the Age of Governance". Public Administration Review, 00(00):1-6. 
Dentchev, Nikolay A., Elvira Haezendonck \& Mitchell van Balen. 2015. "The Role of Governments in the Business and Society Debate". Business \& Society, 1-18

Diefenbach, T., \& Sillince, J. A. A. 2011. "Formal and informal hierarchy in different types of organizations", Organization Studies, 32(11): 15151537.

Dixon, R., Ritchie, J. \& Siwale, J. 2006. "Microfinance: Accountability from the Frassroots",

Accounting Auditing \& Accountability Journal. Vol. 19, No. 3: 405 427.

Dubnick, M. J. 2003. “Accountability and Ethics: Reconsidering the Relationships”, International Journal of Organization Theory and Behavior. Vol. 6 No. 3: 405 - 441.

Dunleavy, P., H. Margetts, S. Bastow \& J. Tinkler. 2006. "New public management is dead: Long live digital-era governance". Journal of Public Administration Research and Theory, 1:467-494.

Eisenhardt, K. M. 1989. “Agency theory: An assessment and review”. Academy of Management

Review, 14(1): 57-74.

Ferranti, D, Jacinto, J, Ody, AJ \& Ramshaw, 2009. How to Improve Governance A New Framework for Analysis and Action, Washington D.C : The Bookings Institution.

Ghosh, M., \& Whalley, J. 2008. "State owned enterprises, shirking and trade liberalization".

Economic Modelling, 25(6): 1206-1215.

Girotra, Karan \& Serguei Netessine. 2014. "Four Paths to Business Model Innovation”. Harvard Business Review, July-August: 98-103.

Goldsmith, Arthur, 1985. "The private sector and rural development: Can agribusiness help the small farmer?". World Development, Volume 13, Issues 10-11, October-November, Pages 1125-1138

Grimmelikhuijsen, Stephan G. \& Mary K. Feeney. 2016.“Developing and Testing an Integrative Framework for Open Government Adoption in Local Governments". Public Administration Review, 00(00):1-12.

Hoskisson, R. E., Hitt, M. A., Johnson, R. A., \& Grossman, W. 2002. "Conflicting voices: The effects of institutional ownership heterogeneity and internal governance on corporate innovation strategies." Academy of Management Journal, 45(4): 697-716. 
Hosseini, Seyed Jamal F., Gerard McElwee, Shohreh Soltani, David J Smith. 2012. "The innovation performance of small rural enterprises and cooperatives in Tehran province, Iran ”. Local Economy, 27(2): 183192.

Hosseini, Seyed Jamal F., Gerard McElwee, Shohreh Soltani, David J Smith. 2012. "The innovation performance of small rural enterprises and cooperatives in Tehran province, Iran ”. Local Economy, 27(2): 183192.

Inoue, C. F. K. V., Lazzarini, S. G., \& Musacchio, A. 2013. "Leviathan as a minority shareholder: Firmlevel implications of state equity purchases". Academy of Management Journal, 56(6): 1775-1801.

Jones, R. Gareth \& George Jennifer M, 2014. Contemporary Management, Eighth Edition, Singapore: Mc. Graw Hill Education.

June, Sethela \& Rosli Mahmood. 2011. "The Relationship between Role Ambiguity, Competency and Person-Job Fit With the Fob Performance of Employees in the Service Sector SMEs in Malaysia", Business Management Dynamics 1(2): 79-98.

Kang, Sangsoon \& Joohee Choi, 2014. "Business Ethics and Government Intervention in The Market in Joseon", Korea Observer, 45(3): $437-$ 460.

Kang, Sangsoon \& Joohee Choi. 2014. "Business Ethics and Government Intervention in the Market in Joseon". Korea Observer, 45(3): 437460.

Keban, Yeremias, 2008. Enam Dimensi Strategis Administrasi Publik, Yogyakarta: Gava Media.

Kernaghan, Kenneth. 2000. "The Post-Bureaucratic Organization and Public Service Values", International Review of Administrative Sciences, 66(1):91-

Kim, Younsung \& Nicole Darnall. 2016. "Business as a Collaborative Partner: Understanding Firms' Sociopolitical Support for Policy Formation”. Public Administration Review, 76(2):326-337.

Kloby, K., 2009, "Less is More: Exploring Citizen-Based Financial Reporting in Local Government", Journal of Public Budgeting, Accounting \& Financial Management, Vol 21 No. 3: 367 - 391

Kloot, L. \& Martin, J., 2001, "Local Government Accountability: Explaining the Differences", 
Kurniasih, D, Setyoko, P \& Imron, M. 2014. Model Penguatan Kelembagaan pada Program Sanitasi Lingkungan Berbasis Masyarakat di Kabupaten Banyumas, Penelitian Unggulan Perguruan Tinggi, Universitas Jenderal Soedirman.

Kurniasih, Denok, Setyoko, Israwan \& Imron, M, 2015. Model Penguatan Kelembagaan pada Program Sanitasi Lingkungan Berbasis Masyarakat di Kabupaten Banyumas, Penelitian Unggulan Universitas Jenderal Soedirman.

Lam, Newman M.K. 2016. "Introduction Business-government relationship in economic development". Asian Education and Development Studies, 5(4): 371-387.

Liang, Xue. 2006. "The evolution of township and village enterprises (TVEs) in China". Journal of Small Business and Enterprise Development, 13(2): $235-241$.

Lodhia, S.K. \& Burritt, R.L. 2004. "Public Sector Accountability Failure in Emerging Economy: Tha Case of The National Bank of Fiji”, The International Journal of Public Sector Management, Vol. 17, No. 4: $345-359$.

Mangematin,Vincent \& Charles Baden-Fuller, (2015), Introduction: Business Models and Modelling Business Models, in Charles Baden-Fuller, Vincent Mangematin (ed.) Business Models and Modelling (Advances in Strategic Management, Volume 33) Emerald Group Publishing Limited, pp.xi - xxii.

Morçöl, Göktug־ \& James F. Wolf. 2010. “Understanding Business Improvement Districts: A New Governance Framework". Public Administration Review, November-December: 906-913.

Mulgan, 2003. Accountability: An Ever-Expanding Concept ?, Public Administration, Vol 78 No.

3.

Najmaei, Arash \& Zahra Sadeghinejad. 2016. "Toward a Theory of Business Models and Business Modeling in Public Entrepreneurship" In New Perspectives on Research, Policy \& Practice in Public Entrepreneurship. Emerald Group Publishing Ltd, 6: 77-102.

Nelissen, N. 2002. The Administrative Capacity of New Types of Governance, Public Organization Review 2(1): 23-43.

Newman, Meredith A. \& Michael J. Gaffney. 2002. "A Clash of Values: Public Ethics and the Business of Government". International Review of Public Administration, 7(1): 17-27. 
O’Doherty, K., Gauvin, F.P., Grogan, C. \& Friedman, W. (2012). Implementing a Public Deliberative Forum. Hastings Center Report, 42(2), 20-23.

Ranerup, Agneta, Helle Zinner Henriksen \& Jonas Hedman. 2016. “An analysis of business models in Public Service Platforms". Government Information Quarterly, 33(1): 6-14.

Remington, Thomas F. 2016. "Regional Variation in Business-Government Relations in Russia and China", Probel of Post Communism, 63: 6374.

Rhodes, Carl. 2016. “Democratic Business Ethics: Volkswagen's emissions scandal and the disruption of corporate sovereignty". Organization Studies, 37(10): 1-18.

Richard, D.\&Smith, MJ, 2002. Governance and Public Policy in The UK, Oxford: Oxford University Press.

Romzek, B. \& Ingraham, P.W., 2000. "Cross Pressure of Accountability: Initiative, Command, and Failure in the Ron Brown Plane Crash", Public Administration Review, Vol. 60. No. 3: 240 - 241.

Schillemans, T., 2008, "Accountability in the Shadow of Hierarchy: The Horizontal

Accountability of Agencies", Public Organization Review, Vol. 8, No. 2: 175-194.

Setyoko, Israwan, 2011. Administrasi Negara dan Kebijakan Publik: Mewujudkan Keadilan Sosial Melalui Proses Deliberatif, Pidato Pengukuhan Guru Besar Universitas Jenderal Soedirman.

Desa (ADD),

2011. Akuntabilitas Administrasi Keuangan Program Alokasi Dana

JIANA: Jurnal Ilmu Administrasi Negara, 111 (1).

$\begin{array}{cl}\begin{array}{c}\text { Kurniasih, } \\ \text { Governance melalui }\end{array} & \begin{array}{l}\text { 2012. Transformasi } \\ \text { Pengembangan }\end{array} \text { Public } \\ \text { Partisipasi Publik di tingkat lokal, Prosiding Seminar Nasional } \\ \text { Transformasi Sosial Budaya di Indonesia, Fisip-Unsoed. }\end{array}$
di Kabupaten ,Kurniasih, Denok \& Imron, M, 2016. Kinerja Badan Usaha Milik Desa Banyumas, Penelitian Unggulan Unsoed.

Shafritz, Jay M \& Hyde, 1997. Classic of Public Administration, California: Cole Publishing Company. 
Smith, Anne MJ. \& Julie McColl. 2016. "Contextual influences on social enterprise management in rural and urban communities". Local Economy, 31(5): 572-588.

Stanley, T, Jennings, N. \& Mack, J., 2008, “An Examination of The Content of Community Financial Report in Queensland Local Government Authorities", Financial Accountability and Management, Vol. 24 No. 4: $411-438$

Steinerowski, Artur A. \& Izabella Steinerowska-Streb. 2012. "Can social enterprise contribute to creating sustainable rural communities? Using the lens of structuration theory to analyse the emergence of rural social enterprise". Local Economy, 27(2): 167-182

Velu, Chander, Mahima Khanna. 2013. "Business model innovation in India", Journal of Indian Business Research, 5(3): 156-170.

Wang, Juan. 2005. "Going Beyond Township and Village Enterprises in Rural China". Journal of Contemporary China, 14(42): 177-187.

Yung-Tai Tang\&Chen-Hua Chang, 2010.'The Impact of Role Ambiguty and Role Conflict on Employee Creativity". African Journal of Bussines Management, 4(6): 869-881.

Yunus, Muhammad, Bertrand Moingeon \& Laurence Lehmann-Ortega. 2010. "Building Social Business Models: Lessons from the Grameen Experience". Long Range Planning, 43: 308-325.

Zulkhibri, Muhamed, 2017. "Rethinking the Catalytic Role of Private Sector for Inclusive Growth". Journal of Development Policy and Practice, Vol 3 , Issue 1, pp. $41-54$. 